\title{
Long-term treatment of spontaneously hypertensive rats with losartan and molecular basis of modulating $I_{t o}$ of ventricular myocytes
}

\author{
HONGMING ZHANG ${ }^{1 *}$, SONGLIN WU ${ }^{2 *}$, CONGXING HUANG ${ }^{2}$ and XIAOYAN LI ${ }^{1 *}$ \\ ${ }^{1}$ Department of Cardiology, The General Hospital of Jinan Military Region, Jinan, Shandong 250031; \\ ${ }^{2}$ Department of Cardiology, Renmin Hospital of Wuhan University, Wuhan, Hubei 430060, P.R. China
}

Received June 24, 2013; Accepted February 7, 2014

DOI: $10.3892 / \mathrm{mmr} .2014 .2001$

\begin{abstract}
The present study aimed to determine the effect of chronic treatment with losartan on transient outward potassium current $\left(I_{\mathrm{to}}\right)$ and the expression levels of potassium voltage-gated channel subfamily D members 2 and 3 (Kv4.2 and 3) and voltage-gated potassium channel-interacting protein 2 (KChIP2) in rats. Spontaneously hypertensive (SH) rats and Wistar-Kyoto (WKY) rats were used in the study. The rats were divided into los-SH and $\mathrm{SH}$ groups and los-WKY and WKY groups, respectively. $I_{\text {to }}$ was recorded and expression levels of Kv4.2, Kv4.3 and KChIP2 were measured by western blot analysis and quantitative polymerase chain reaction. $I_{\text {to }}$ current density was smaller in $\mathrm{SH}$ compared with WKY, los-WKY and los-SH groups $(\mathrm{P}<0.01)$. Inactivation time constant of myocytes was larger in $\mathrm{SH}$ compared with WKY, los-WKY and los-SH groups $(\mathrm{P}<0.01)$. The mean levels of mRNA and protein of Kv4.2 and Kv4.3 were significantly lower in the SH compared with WKY, los-WKY and los-SH groups in vivo and in vitro $(\mathrm{P}<0.01)$. The Pearson statistical test showed no correlation between the expression levels of $\mathrm{Kv} 4.2, \mathrm{Kv} 4.3, \mathrm{KChIP} 2$ and the changes in blood pressure in the losartan treatment group. In conclusion, chronic blockade of angiotensin II type 1 receptors with losartan reversed $\mathrm{SH}$ rats' electrical remodeling and shortened action potential duration, which was associated with an increase in $I_{\text {to }}$ density as the
\end{abstract}

Correspondence to: Dr Hongming Zhang, Department of Cardiology, The General Hospital of Jinan Military Region, 25 Shifan Road, Tianqiao District, Jinan, Shandong 250031, P.R. China

E-mail: hongmingzhang1@sina.com

Dr Songlin Wu, Department of Cardiology, Renmin Hospital of Wuhan University, Wuhan, Hubei 430060, P. R. China

E-mail: wusonglin222@163.com

${ }^{*}$ Contributed equally

Key words: losartan, patch-clamp technique, potassium current, reverse transcription-polymerase chain reaction, western blotting expression levels of Kv4.2, Kv4.3 increased and the expression levels of KChIP2 decreased. However, the expression levels of $\mathrm{Kv} 4.2, \mathrm{Kv} 4.3$ and KChIP2 were not correlated with the change in blood pressure in the losartan treatment group. Losartan may decrease the inactivation time by increasing the expression of KChIP2.

\section{Introduction}

Angiotensin receptor blockers (ARBs) have increasingly become part of the first line of treatment against hypertensive diseases, and losartan was shown to improve cardiovascular morbidity and mortality in patients with isolated systolic hypertension and left ventricular (LV) hypertrophy (1). The reduction in ventricular arrhythmias (VAs) appears to be associated with the regression of myocardial hypertrophy and fibrosis (2). This may be a consequence of depressurization and hypertrophic changes. However, it has been shown that the angiotensin II type $1\left(\mathrm{AT}_{1}\right)$ receptor antagonist reduced heart rate and QT dispersion in hypertensive patients and the two actions were independent of changes in blood pressure (BP) (3). $\mathrm{AT}_{1}$ antagonist losartan directly modified the human cardiac repolarizing $\mathrm{K}^{+}$currents (4), which means that the reduction in VAs may not be a consequence of depressurization and hypertrophic changes. The present study tested the hypothesis that the $\mathrm{AT}_{1}$ receptor antagonist reversed repolarization abnormities of LV myocytes in spontaneously hypertensive (SH) rats which was independent of changes in BP.

Hypertrophied hearts also show significant electrophysiological changes. The most consistent electrical abnormality is prolongation of the action potential duration (APD) (5). AP prolongation at the early stages of cardiac hypertrophy may be linked to the upregulation of the calcium current $\left(I_{\mathrm{Ca}}\right)$ and the downregulation of the transient outward potassium current $\left(I_{\text {to }}\right)$. Once cellular hypertrophy is established, only reduced $I_{\text {to }}$ persists (5). Molecular biological studies have identified that potassium voltage-gated channel subfamily D members 2 and 3 (Kv4.2 and 3) $\alpha$-subunits and voltage-gated potassium channel-interacting protein 2 (KChIP2) $\beta$-subunits are likely to contribute significantly to $I_{\text {to }}$ in rat ventricular myocytes (6). SH rats are a model widely studied to accelerate the understanding of human essential hypertension 
due to the opportunity to control environmental and genetic confounders (7). SH rats were contrasted with their progenitor strain of normotensive Wistar-Kyoto (WKY) rats. In middle-aged SH rats the incidence of VAs is higher compared with the age-matched normotensive rats (7).

In the present study, the effect of chronic treatment with losartan on $I_{\text {to }}$ and the expression of Kv4.2, Kv4.3 and KChIP2 in SH rats with cardiac hypertrophy was evaluated. It was also determined whether it occurred independent of changes in BP.

\section{Materials and methods}

Ethics statement. The animal study was conducted according to the Guide for the Care and Use of Laboratory Animals published by the US National Institutes of Health (NIH publication no. 85-23, revised 1996) and the protocol was approved by the Animal Research Committee of Wuhan University (Wuhan, China).

Animals. A total of 24 18-week-old male SH rats weighing $330-360 \mathrm{~g}$ were randomly divided into two groups (12 rats in each): Losartan-treated [los-SH group, $10 \mathrm{mg} / \mathrm{kg}^{-1} / \mathrm{d}^{-1}$, intragastric administration (ig)] (8) and $\mathrm{SH}$ group. A total of 24 18-week-old male WKY rats weighing 330-360 g were randomly divided into two groups (12 rats in each): Losartan-treated (los-WKY; $10 \mathrm{mg} / \mathrm{kg}^{-1} / \mathrm{d}^{-1}$, ig) and WKY. Two losartan-treated groups were administered losartan dissolved in tap water for eight weeks, and SH and WKY groups received only tap water during the same time period. All rats were supplied by the experimental animal center of Wuhan University Medical College (Wuhan, China) and bred in our laboratory. All rats were housed in individual cages and fed a standard diet and tap water ad libitum. They were maintained in a quiet room at constant temperature $\left(20-22^{\circ} \mathrm{C}\right)$ and humidity (50-60\%) with 12-h light/dark cycle.

Isolation of ventricular myocytes. LV myocytes were isolated according to methods previously described (5). Briefly, rats were sacrificed by cervical dislocation. The heart was rapidly removed and mounted on a Langendorff apparatus by aortic cannulation. The heart was first perfused for $5 \mathrm{~min}$ at $35^{\circ} \mathrm{C}$ with calcium-free Tyrode's solution containing $\mathrm{NaCl} 140 \mathrm{mmol} / \mathrm{l}^{-1}$, $\mathrm{KCl} 5.4 \mathrm{mmol} / \mathrm{l}^{-1}, \mathrm{NaH}_{2} \mathrm{PO}_{4} 0.33 \mathrm{mmol} / \mathrm{l}^{-1}, \mathrm{MgCl}_{2} 0.5 \mathrm{mmol} / \mathrm{l}^{-1}$, HEPES $5 \mathrm{mmol} / \mathrm{l}^{-1}$ and glucose $5.5 \mathrm{mmol} / \mathrm{l}^{-1}$ (pH 7.4 with $\mathrm{NaOH}$ ), and then the heart was perfused for 12-15 min with the same solution containing $80 \mu \mathrm{mol} / \mathrm{l}^{-1} \mathrm{Ca}^{2+}$ and collagenase I $0.33 \mathrm{~g} / 1^{-1}$, bovine serum albumin (BSA) $0.25 \mathrm{~g} / 1^{-1}$ and protease E $0.25 \mathrm{~g} / \mathrm{l}^{-1}$. Next, the heart was washed out with calcium-free Tyrode's solution. The heart was removed from the Langendorff apparatus and the LV tissue was dissected into small sections and gently agitated in $2 \mathrm{mmol} / \mathrm{l}^{-1}$ $\mathrm{CaCl}_{2}$-containing Tyrode's solution. The cells were suspended in modified Kreb's solution (K-glutamate $100 \mathrm{mmol} / \mathrm{l}^{-1}$, K-aspartate $10 \mathrm{mmol} / \mathrm{l}^{-1}, \mathrm{KCl} 25 \mathrm{mmol} / \mathrm{l}^{-1}$, glucose $20 \mathrm{mmol} / \mathrm{l}^{-1}$, $\mathrm{KH}_{2} \mathrm{PO}_{4} 10 \mathrm{mmol} / \mathrm{l}^{-1}$, HEPES $5 \mathrm{mmol} / \mathrm{l}^{-1}, \mathrm{MgSO}_{4} 2 \mathrm{mmol} / \mathrm{l}^{-1}$, taurine $20 \mathrm{mmol} / \mathrm{l}^{-1}$, creatine $5 \mathrm{mmol} / \mathrm{l}^{-1}$, EGTA $0.5 \mathrm{mmol} / \mathrm{l}^{-1}$ and $0.1 \%$ BSA, pH 7.4 with $\mathrm{KOH}$ ) and stored at room temperature for $2 \mathrm{~h}$ prior to use and used within $10 \mathrm{~h}$ of isolation. The reagents are products of Sigma-Aldrich (St. Louis, MO, USA).
Electrophysiological methods. The ruptured patch whole-cell configuration was used as described previously (9). The isolated cells were transferred to an open perfusion chamber mounted on the stage of an inverted microscope (model IMT2; Olympus Corporation, Tokyo, Japan). Following being set to the bottom of the chamber, cells were perfused with Tyrode's solution that contained $\mathrm{NaCl} 140 \mathrm{mmol} / \mathrm{l}^{-1}, \mathrm{KCl} 5.4 \mathrm{mmol} / \mathrm{l}^{-1}$, $\mathrm{Na}_{2} \mathrm{HPO}_{4} 1 \mathrm{mmol} / \mathrm{l}^{-1}$, HEPES $5 \mathrm{mmol} / \mathrm{l}^{-1}$, glucose $10 \mathrm{mmol} / \mathrm{l}^{-1}$, $\mathrm{MgCl}_{2} 1 \mathrm{mmol} / \mathrm{l}^{-1}$ and $\mathrm{CaCl}_{2} 1 \mathrm{mmol} / \mathrm{l}^{-1}(\mathrm{pH} 7.35$ with $\mathrm{NaOH}$ ) to wash out the dead cells. Only quiescent rod-shaped cells showing clear cross striations were used. The external solutions were gassed with $100 \% \mathrm{O}_{2}$. Whole-cell membrane currents were recorded with a patch-clamp technique using Pulse+Pulsefit software (version 8.31; HEKA Elektronik, Lambrecht, Germany) and a patch amplifier (EPC-9; HEKA Elektronik). Glass pipette electrodes were forged by a micropipette puller (PB-7; Narishige, Tokyo, Japan) and the resistance was 2-4 M $\Omega$. The current signal was filtered with a low-pass filter and digitized by an A/D converter (Labmaster 1600; Labmaster Oy Ltd., Aura, Finland) under the control of a computer (IBM PC/AT; IBM, Armonk, NY, USA) and stored on a hard disk for later analysis. The liquid junction potential was corrected following immersion of the pipette in the solution. Following establishment of a tight pipette-membrane seal (seal resistance $>1 \mathrm{GW}$ ), fast capacitance was compensated, the membrane was ruptured with gentle suction to obtain the whole-cell voltage-clamp configuration and slow capacitance and series resistance were compensated. Data were analyzed using the software program pCLAMP (Axon Instruments, Inc., Sunnyvale, CA, USA). Temperature was maintained at $20^{\circ} \mathrm{C}$.

Tyrode's solution for $I_{\text {to }}$ (normal solution plus $0.5 \mathrm{mmol} / \mathrm{l}^{-1}$ $\mathrm{CdCl}_{2}$, used to block calcium current). The intracellular solution contained $\mathrm{KCl} 20 \mathrm{mmol} / \mathrm{l}^{-1}$, K-aspartate $110 \mathrm{mmol} / \mathrm{l}^{-1}$, $\mathrm{MgCl}_{2} 1.0 \mathrm{mmol} / \mathrm{l}^{-1}, 2$-[4-(2-hydroxyethyl)piperazin-1-yl] ethanesulfonic acid $10 \mathrm{mmol} / \mathrm{l}^{-1}$, ethylene glycol tetraacetic acid $5 \mathrm{mmol} / \mathrm{l}^{-1}$ and bisodium adenosine triphosphate $5 \mathrm{mmol} / \mathrm{l}^{-1}$ (pH 7.3 with $\mathrm{KOH}$ ). The $I_{\text {to }}$ was evoked by steps in the range between -40 and $70 \mathrm{mV}$ from a holding potential (HP) of $-70 \mathrm{mV}$ (sampling rate, $5 \mathrm{kHz}$ ); a prestep to $-40 \mathrm{mV}$ was used to inactivate the sodium current. Series resistance and membrane capacitance were compensated by $80 \%$ to minimize the capacitive transient. $I_{\text {to }}$ was measured as the peak outward current at the beginning of the depolarizing step and normalized with respect to the membrane capacitance value. Recovery from inactivation was evaluated by applying double pulses to $60 \mathrm{mV}$, separated by intervals of 5-300 msec. APs were elicited by a brief ( $2 \mathrm{msec}$ ) suprathreshold pulse applied at a frequency of $2 \mathrm{~Hz}$. Cell membrane capacitance was measured by applying a $\pm 10 \mathrm{mV}$ pulse starting from a $\mathrm{HP}$ of $-70 \mathrm{mV}$.

Quantitative polymerase chain reaction $(q P C R)$. The gene-specific sequences of oligonucleotide primers (Table I) were used to check the expression of respective genes with a ABI-Prism 7700 Sequence Detection system (Applied Biosystems, Inc., Foster City, CA, USA) and a $1 \mathrm{X}$ final concentration of SYBR ${ }^{\circledR}$-Green PCR Master mix containing SYBR-Green I dye, AmpliTaq Gold DNA Polymerase, dNTPs and optimized buffer components, and $0.25 \mathrm{U} / \mathrm{ml}$ MultiScribe Reverse Transcriptase, $0.4 \mathrm{U} / \mathrm{ml}$ RNase inhibitor 
Table I. Primers of Kv4.2, Kv4.3, KChIP2 and GAPDH used in this study.

\begin{tabular}{ll}
\hline Primer & \multicolumn{1}{c}{ Sequence } \\
\hline Kv4.2 & Forward: 5'-CTTCACTATCCCCGCCATGA-3'; Reverse: 5'-ATGACTGAGACGGCAATGAA-3' \\
Kv4.3 & Forward: 5'-GAGCTGACCGGCACCCCA-3'; Reverse: 5'-TGTTTTGCAGTTTGGTCTCAGTC-3' \\
KChIP2 & Forward: 5'-GCTCCTATGACCAGCTTACGG-3'; Reverse: 5'-CTCGTTGACAATCCCACTGG-3' \\
GAPDH & Forward: 5'-GCCATCACTGCCACTCAG-3'; Reverse: 5'-GTGAGCTTCCCGTTCAGC-3'
\end{tabular}

Kv4.2 and 3, potassium voltage-gated channel subfamily D members 2 and 3; KChIP2 voltage-gated potassium channel-interacting protein 2.

and $10 \mathrm{ng}$ tissue RNA in a $50 \mu \mathrm{l}$ PCR mixture, according to the manufacturer's instructions (Applied Biosystems, Inc.). PCR amplification was performed on a PTC-200 Peltier Thermal cycler (MJ Research, Edison, NJ, USA). The temperature profile included an initial $30 \mathrm{~min}$ cycle at $48^{\circ} \mathrm{C}$ (for cDNA synthesis) and denaturation at $95^{\circ} \mathrm{C}$ for $10 \mathrm{~min}$ to deactivate the reverse transcription and activate the ThermoScript Taq polymerase. This was immediately followed by 40 cycles of denaturation at $95^{\circ} \mathrm{C}$ for $15 \mathrm{sec}, 60 \mathrm{sec}$ at $60^{\circ} \mathrm{C}$ annealing and $60 \mathrm{sec}$ at $72^{\circ} \mathrm{C}$ elongation using the optical function for fluorescence monitoring. The relative quantification of gene expression by qPCR in a sample was determined by comparing the target-amplified product against GAPDH (internal standard) within the same sample.

Membrane protein extraction and western blot analysis. Membrane proteins were extracted from isolated LV cardiomyocytes. Following isolation, cells were centrifuged at $1,000 \mathrm{x} g$ for $5 \mathrm{~min}$. The supernatant was discarded and the cells were resuspended in lysis buffer (Tris- $\mathrm{HCl} 5 \mathrm{mmol} / \mathrm{l}^{-1}$, EDTA $2 \mathrm{mmol} / \mathrm{l}^{-1}$ and benzamidine $10 \mu \mathrm{g} / \mathrm{ml}$, leupeptin $5 \mu \mathrm{g} / \mathrm{ml}$ and soybean trypsin inhibitor $5 \mu \mathrm{g} / \mathrm{ml}$ ). The suspension was homogenized and centrifuged at $1,000 \mathrm{x} \mathrm{g}$ to pellet cellular debris and the remaining supernatant was centrifuged at $45,000 \mathrm{x}$ g at $4^{\circ} \mathrm{C}$ for $20 \mathrm{~min}$. The pellet was resuspended in resuspension buffer (Tris- $\mathrm{HCl} 75 \mathrm{mmol} / \mathrm{l}^{-1}$, EDTA $2 \mathrm{mmol} / \mathrm{l}^{-1}$, $\mathrm{MgCl}_{2} 12.5 \mathrm{mmol} / \mathrm{l}^{-1}$ and soybean trypsin inhibitor $5 \mu \mathrm{g} / \mathrm{ml}$ ). Total protein concentration was determined using the Bradford assay.

Western blot analysis was performed to measure Kv4.2, Kv4.3, KChIP2 and GAPDH proteins. Following separation by $10 \%$ SDS-PAGE, proteins were transferred to polyvinylidene sulfonyl fluoride membranes (Bio-Rad, Hercules, CA, USA) in Tris/glycine transfer buffer containing 5\% methanol and $0.05 \%$ sodium dodecyl sulfate. Membranes were blocked with $5 \%$ nonfat milk in phosphate-buffered saline (PBS) supplemented with $0.05 \%$ Tween-20 (PBS-T), for $1 \mathrm{~h}$ at room temperature and incubated with primary antibody (1:200) [rabbit polyclonal antibodies against Kv4.2 or Kv4.3 were purchased from Chemicon (Temecula, CA, USA), KChIP2 from Affinity BioReagents (Golden, CO, USA) and a mouse monoclonal antibody against GAPDH was purchased from Research Diagnostics, Inc. (Flanders, NJ, USA)] at $4^{\circ} \mathrm{C}$ overnight. The membrane was washed six times for $5 \mathrm{~min}$ with PBS-T and incubated with primary and secondary antibodies (anti-rabbit or anti-mouse antibodies conjugated with horseradish peroxidase were purchased from Amersham Pharmacia
Biotech, Amersham, UK) diluted at 1:500 in PBS-T. Following six further washes in PBS-T, blots were visualized with the Chemi-Imager 5500 (Alpha Innotech, San Leandro, CA, USA). Finally, the amount of target protein, normalized to an endogenous reference GAPDH, was calculated.

Culture of rat cardiomyocytes and qPCR, membrane protein extraction and western blot analysis in vitro. The cardiomyocytes of SH and WKY rats were harvested in accordance with the aforementioned procedure. The cell suspension obtained (1-2 drops) was layered onto sterile laminin-coated cover slips and incubated for $30 \mathrm{~min}\left(37^{\circ} \mathrm{C}\right.$ in $\left.5 \% \mathrm{CO}_{2} / 95 \% \mathrm{O}_{2}\right)$ to allow cell attachment. Plating media (Dulbecco's modified Eagle medium containing $10 \%$ fetal bovine serum, $5 \mathrm{U} / \mathrm{ml}$ each of penicillin and streptomycin) was gently added. Losartan $\left(10^{-7} \mathrm{~mol} / \mathrm{l}\right)(10)$ was added to the plating media of cells from six SH and six WKY rats. Experiments were performed between 18-20 h. qPCR, membrane protein extraction and western blot analysis were performed in accordance with the aforementioned methods.

Statistical analysis. All values are expressed as means \pm standard error. Paired and unpaired Student's t-tests were used as appropriate to evaluate the statistical significance of differences between two group means and analysis of variance was used for multiple groups. The Pearson correlation coefficients between the mRNA, protein expression level of Kv4.2, Kv4.3, $\mathrm{KChIP} 2$ and the change from baseline in BP were calculated. All data were normalized prior to statistical analysis. All statistical tests were two-tailed. $\mathrm{P}<0.05$ was considered to indicate a statistically significant difference between values. Statistical analyses were performed using SPSS 11.5 statistical package (SPSS, Inc., Chicago, IL, USA).

\section{Results}

Systolic BP, cardiac index and membrane capacitance. There were no differences in body weight among the aforementioned four groups prior to and following the experiment ( $\mathrm{P}>0.05$; Table II). Systolic BP values at the age of 18 weeks were significantly higher in the $\mathrm{SH}$ and los-SH groups compared with the WKY and los-WKY groups $(\mathrm{P}<0.05)$. At the age of 26 weeks, the systolic BP value was higher in SH compared with the los-SH, los-WKY and WKY groups $(\mathrm{P}<0.05)$. The heart weight, cardiac index (the heart to body weight ratio) and the mean cell membrane capacitance were significantly greater in los-SH and $\mathrm{SH}$ groups compared with 
Table II. Body weight, systolic blood pressure, heart weight, heart to body weight ratio and membrane capacitance of rats.

\begin{tabular}{|c|c|c|c|c|c|c|c|}
\hline \multirow[b]{2}{*}{ Groups $(n=12)$} & \multicolumn{2}{|c|}{ Body weight (g) } & \multicolumn{2}{|c|}{$\begin{array}{l}\text { Systolic blood pressure } \\
\qquad(\mathrm{mmHg})\end{array}$} & \multicolumn{3}{|c|}{$\begin{array}{l}\text { Parameters } \\
26 \text { week }\end{array}$} \\
\hline & 18 weeks & 26 weeks & 18 weeks & 26 weeks & Heart weight (g) & HW/BW (mg/g) & Capacitance $(\mathrm{pF})$ \\
\hline WKY & $344 \pm 26.7$ & $376 \pm 27.5^{\mathrm{a}}$ & $88 \pm 11.6^{\mathrm{b}}$ & $90 \pm 11.9^{b}$ & $1.23 \pm 0.25$ & $3.71 \pm 0.28$ & $187.65 \pm 55.51$ \\
\hline $\mathrm{SH}$ & $345 \pm 27.1$ & $381 \pm 27.6^{\mathrm{a}}$ & $190 \pm 12.4$ & $198 \pm 13.9$ & $1.89 \pm 0.06^{\mathrm{c}}$ & $5.68 \pm 0.46^{c}$ & $276.32 \pm 66.87^{c}$ \\
\hline Los-SH & $342 \pm 27.2$ & $374 \pm 26.9^{a}$ & $190 \pm 12.6$ & $112 \pm 12.3^{\mathrm{a}, \mathrm{b}}$ & $1.72 \pm 0.35^{\mathrm{c}}$ & $5.14 \pm 0.45^{\mathrm{c}}$ & $234.67 \pm 60.92^{c}$ \\
\hline Los-WKY & $346 \pm 27.0$ & $379 \pm 26.7^{\mathrm{a}}$ & $88 \pm 11.8^{\mathrm{b}}$ & $85 \pm 12.4^{\mathrm{b}}$ & $1.19 \pm 0.26$ & $3.68 \pm 0.27$ & $181.43 \pm 55.37$ \\
\hline
\end{tabular}

${ }^{\text {aP }}<0.01$, vs. 18 weeks; ${ }^{b} \mathrm{P}<0.01$, vs. SH group and ${ }^{\mathrm{c}} \mathrm{P}<0.01$, vs. WKY and los-WKY groups. Cell membrane capacitance was measured by applying a $\pm 10 \mathrm{mV}$ pulse starting from a holding potential of $-70 \mathrm{mV}$. For capacitance: WKY group (hearts, $\mathrm{n}=12$; cells, $\mathrm{n}=25$ ); los-SH group (hearts, $n=12$; cells, n=24); SH group (hearts, $n=12$; cells, n=26) and los-WKY group (hearts, $n=12$; cells, $n=25$ ). HW, heart weight; BW, body weight; WKY, Wistar-Kyoto; SH, spontaneously hypertensive; los-, losartan-treated.

Table III. Action potential of the rats.

\begin{tabular}{|c|c|c|c|c|}
\hline Groups & $\mathrm{RP}, \mathrm{mV}$ & $\mathrm{APA}, \mathrm{mV}$ & $\mathrm{APD}_{50}, \mathrm{msec}$ & $\mathrm{APD}_{90}, \mathrm{msec}$ \\
\hline WKY (cells, n=25) & $77.54 \pm 2.71$ & $96.87 \pm 8.03$ & $15.71 \pm 3.34^{\mathrm{a}, \mathrm{b}}$ & $63.21 \pm 10.61^{\mathrm{a}, \mathrm{b}}$ \\
\hline SH (cells, n=26) & $78.42 \pm 2.82$ & $98.85 \pm 8.17$ & $24.63 \pm 4.48$ & $92.69 \pm 13.32$ \\
\hline Los-SH (cells, n=24) & $77.90 \pm 2.68$ & $98.52 \pm 8.61$ & $17.04 \pm 3.82^{\mathrm{a}, \mathrm{b}}$ & $71.32 \pm 11.17^{\mathrm{a}, \mathrm{b}}$ \\
\hline Los-WKY (cells, n=25) & $77.68 \pm 2.73$ & $96.87 \pm 8.03$ & $13.54 \pm 3.27^{\mathrm{a}}$ & $60.54 \pm 10.24^{\mathrm{a}}$ \\
\hline
\end{tabular}

${ }^{\mathrm{a}} \mathrm{P}<0.01$, vs. $\mathrm{SH}$ group and ${ }^{\mathrm{b}} \mathrm{P}<0.05$, vs. los-WKY group. RP, resting potential; APA, amplitude of action potential; $\mathrm{APD}_{50}$, action potential duration measured at $50 \%$ repolarization; $\mathrm{APD}_{90}$, action potential duration measured at $90 \%$ repolarization; WKY, Wistar-Kyoto; SH, spontaneously hypertensive; los-, losartan-treated.

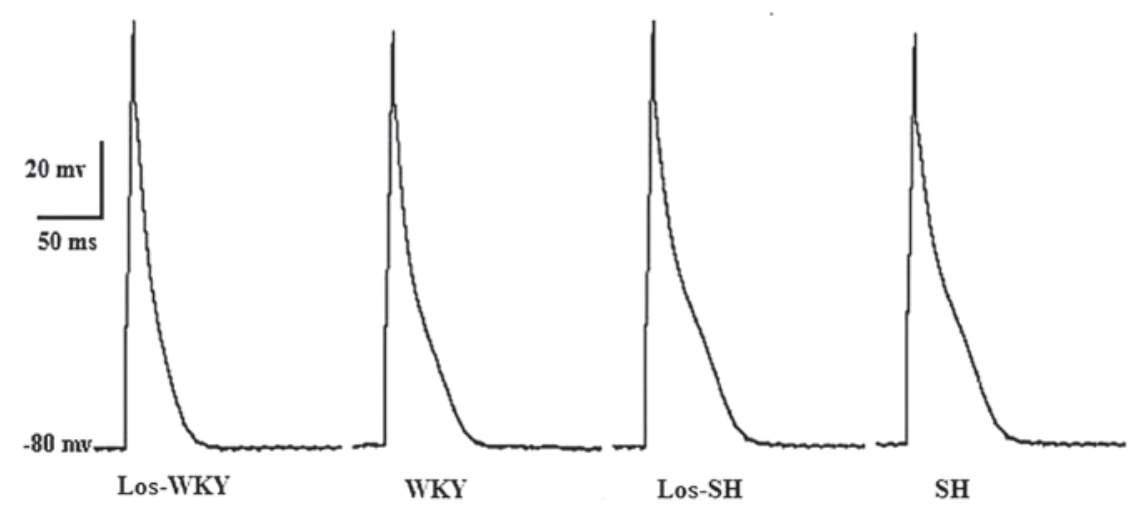

Figure 1. APs were recorded from cells isolated from rat hearts. APs were elicited by a brief $(2 \mathrm{msec})$ suprathreshold pulse applied at a frequency of $2 \mathrm{~Hz}$. APs, action potentials; WKY, Wistar-Kyoto; SH, spontaneously hypertensive; los-, losartan-treated.

the WKY and los-WKY groups following the experiment $(\mathrm{P}<0.01)$.

Action potential. Action potential durations (APD) measured at $50 \%$ repolarization $\left(\mathrm{APD}_{50}\right)$ and $\mathrm{APD}$ measured at $90 \%$ repolarization $\left(\mathrm{APD}_{90}\right)$ were significantly shorter in WKY, los-WKY and los-SH groups compared with the SH group $(\mathrm{P}<0.01$; Table III and Fig. 1$) . \mathrm{APD}_{50}$ and $\mathrm{APD}_{90}$ were longer in $\mathrm{SH}$ compared with the WKY group $(\mathrm{P}<0.01)$. $\mathrm{APD}_{50}$ and $\mathrm{APD}_{90}$ were shorter in los-SH and los-WKY comared with the $\mathrm{SH}$ and WKY groups $(\mathrm{P}<0.05)$. There was no differ- ences in resting potential (RP) and amplitude of action potential (APA) among the aforementioned four groups $(\mathrm{P}>0.05)$.

Transient $I_{t o}$. The $I_{\text {to }}$ amplitude was lower in the SH compared with the WKY, los-WKY and los-SH groups (Fig. 2), the amplitude of $I_{\text {to }}$ at $70 \mathrm{mV}$ was lower in SH compared with WKY, los-WKY and los-SH groups $(\mathrm{P}<0.01)$ (Fig 3). The $I_{\text {to }}$ amplitude was higher in los-WKY compared with WKY and los-SH groups $(\mathrm{P}<0.05)$ (Fig. 3). When normalized to cell membrane capacitance, the $I_{\text {to }}$ current density in SH was smaller compared 


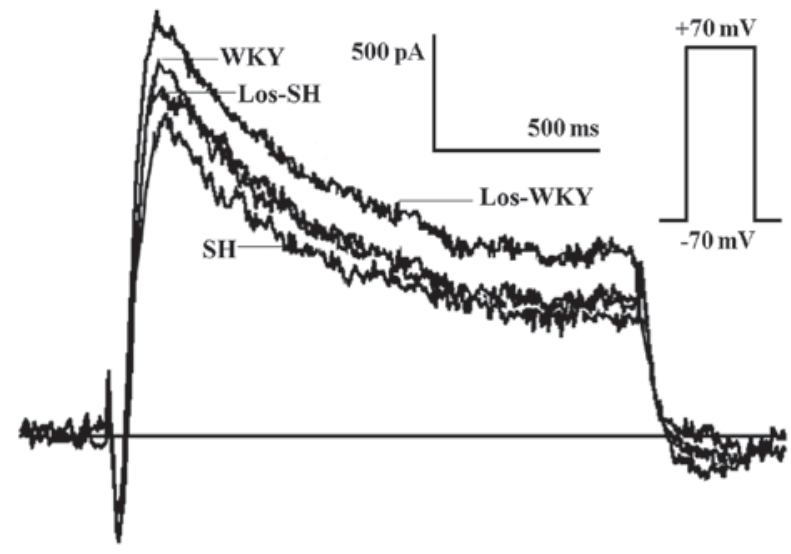

Figure 2. Typical recordings of $I_{t o}$ in rat ventricular myocytes. The $I_{t o}$ was evoked by steps in the range of -40 to $70 \mathrm{mV}$ from a holding potential of $-70 \mathrm{mV}$ (sampling rate, $5 \mathrm{kHz}$ ); a prestep to $-40 \mathrm{mV}$ was used to inactivate sodium current. Dashed lines indicate zero current level. $I_{t o}$, transient outward potassium current; WKY, Wistar-Kyoto; SH, spontaneously hypertensive; los-, losartan-treated.

The mean Ito amplitude at $+70 \mathrm{mV}$

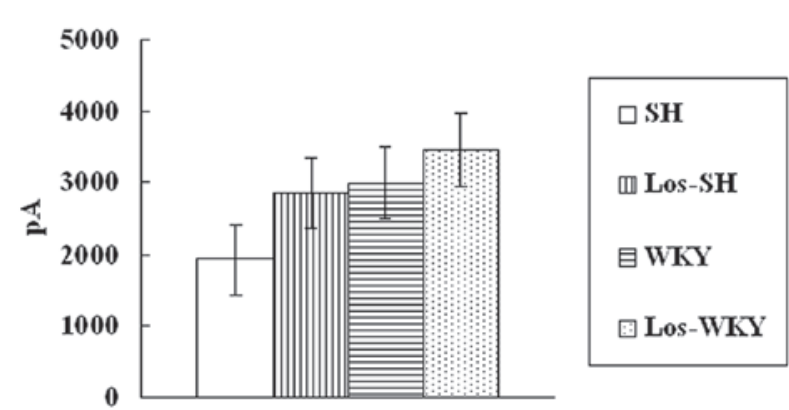

Figure 3. The mean amplitude of $I_{t o}$ at $70 \mathrm{mV}$ was lower in SH $(1,934 \pm 241.5)$ than in the WKY $(3,012 \pm 345.8)$, los-WKY $(3,458 \pm 363.4)$ and los-SH groups $(2,865 \pm 324.9)(\mathrm{P}<0.01)$. The $I_{t o}$ amplitude was higher in the los-WKY than in the WKY and los-SH groups $(\mathrm{P}<0.05) . I_{t o}$, transient outward potassium current; WKY, Wistar-Kyoto; SH, spontaneously hypertensive; los-, losartan-treated.

with that in the WKY, los-WKY and los-SH groups $(40-70 \mathrm{mV}$; $\mathrm{P}<0.01$ ) (Fig. 4).

Kinetic properties of $I_{\mathrm{to}}$. The kinetic properties of $I_{\mathrm{to}}$ were analyzed. Inactivation, steady-state inactivation and recovery from inactivation of $I_{\text {to }}$ was recorded from myocytes of rats (Figs. 5-7 and Table IV).

The inactivation time constant was larger in myocytes isolated from SH compared with WKY, los-WKY and los-SH groups $(\mathrm{P}<0.01)$ (Fig. 5). There were no differences in average steady-state inactivation curves of $I_{\text {to }}$ (Fig. 6) and recovery time constants among the four groups $(\mathrm{P}>0.05)$ (Fig. 7).

Expression of Kv4.2, Kv4.3 and KChIP2 in vivo. The expression levels of Kv4.2 and Kv4.3 were significantly lower in myocytes from SH compared with WKY, los-WKY and los-SH groups $(\mathrm{P}<0.01$; Figs. 8-12), while they were significantly higher in los-WKY compared with WKY and los-SH groups $(\mathrm{P}<0.05)$. The expression levels of KChIP2 were significantly higher in $\mathrm{SH}$ compared with WKY, los-WKY and los-SH groups $(\mathrm{P}<0.01)$,

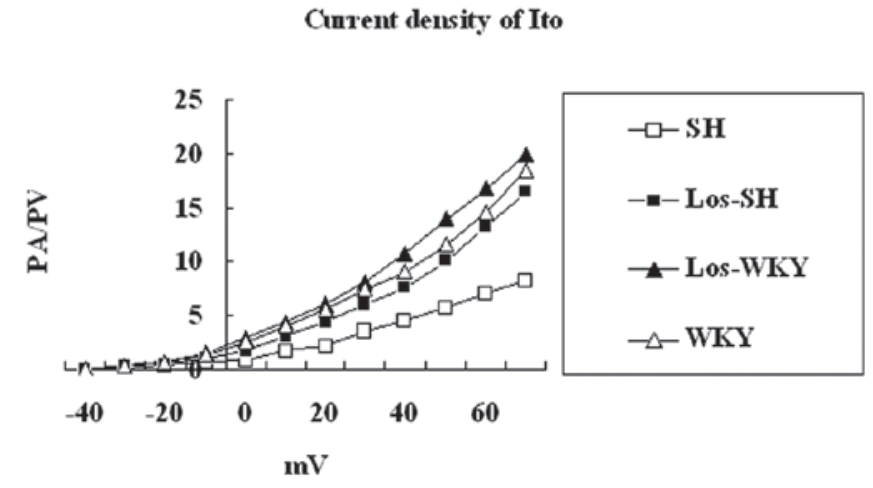

Figure 4. $I_{t o}$ density; SH had a smaller current density than los-SH, los-WKY and WKY groups $(40-70 \mathrm{mV}, \mathrm{P}<0.01)$. Current densities were not significantly different between los-SH, los-WKY and WKY groups ( $>>0.05)$. WKY group (hearts, $\mathrm{n}=12$; cells, $\mathrm{n}=25)$, los-SH group $(\mathrm{N}=12$ hearts, $\mathrm{n}=24$ cells), $\mathrm{SH}$ group (hearts, $\mathrm{n}=12$; cells, $\mathrm{n}=26$ ), los-WKY group (hearts, $\mathrm{n}=12$; cells, $\mathrm{n}=25$ ). $I_{t o}$, transient outward potassium current; WKY, Wistar-Kyoto; SH, spontaneously hypertensive; los-, losartan-treated.

\section{Inactivation}

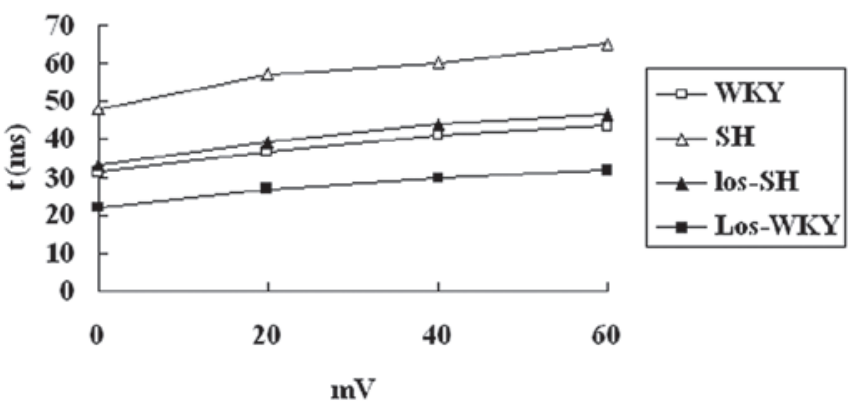

Figure 5. Inactivation time constants of $I_{t o}$ were estimated at holding potentials ranging $0-60 \mathrm{mV}$ by biexponential fitting of the current decay, yielding a short time constant $<100 \mathrm{msec}$ and a long time constant in the range of $1 \mathrm{sec}$. $I_{t o}$, transient outward potassium current; WKY, Wistar-Kyoto; SH, spontaneously hypertensive; los-, losartan-treated.

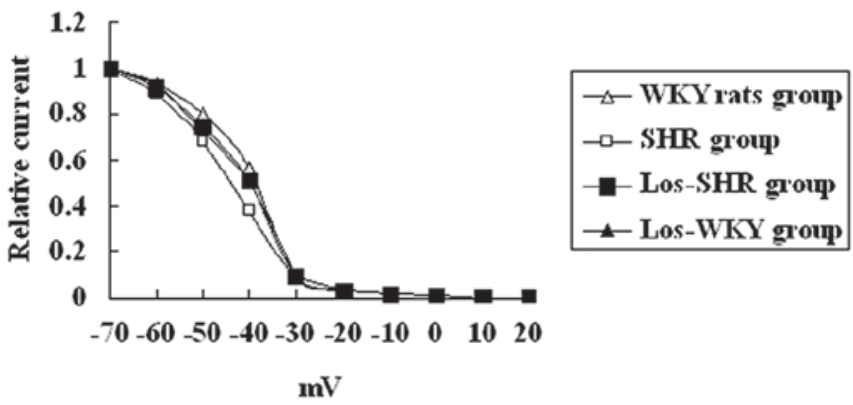

Figure 6. Steady-state inactivation of $I_{t o}$ was determined by a two-step pulse. A conditioning pulse of $600 \mathrm{msec}$ duration ranging between -80 and $10 \mathrm{mV}$ in steps of $10 \mathrm{mV}$ was followed by a step to $60 \mathrm{mV}$ for $600 \mathrm{msec}$. $I_{t o}$, transient outward potassium current; WKY, Wistar-Kyoto; SH, spontaneously hypertensive; los-, losartan-treated.

and were significantly higher in WKY and los-SH compared with the los-WKY group $(\mathrm{P}<0.05)$. No significant difference was observed in mRNA and protein expression levels of Kv4.2, Kv4.3 and KChIP2 between WKY and los-SH group ( $\mathrm{P}>0.05)$. In los-SH and los-WKY groups, expression of Kv4.2 and Kv4.3 
Table IV. Kinetic properties of $I_{t o}$ in rats.

\begin{tabular}{lcccc}
\hline & $\begin{array}{c}\text { WKY group, } \\
\text { cells, } \mathrm{n}=25\end{array}$ & $\begin{array}{c}\text { SH group, } \\
\text { cells, } \mathrm{n}=26\end{array}$ & $\begin{array}{c}\text { Los-SH group, } \\
\text { cells, } \mathrm{n}=24\end{array}$ & $\begin{array}{c}\text { Los-WKY group, } \\
\text { cells, } \mathrm{n}=25\end{array}$ \\
\hline$\tau(0 \mathrm{mV})(\mathrm{msec})$ & $31.23 \pm 1.45$ & $47.73 \pm 2.57$ & $34.71 \pm 2.46$ & $22.41 \pm 1.58$ \\
$\tau(20 \mathrm{mV})(\mathrm{msec})$ & $39.92 \pm 3.27^{\mathrm{a}, \mathrm{b}}$ & $58.19 \pm 3.14$ & $43.44 \pm 3.39^{\mathrm{a}, \mathrm{b}}$ & $27.43 \pm 3.10^{\mathrm{a}}$ \\
$\tau(40 \mathrm{mV})(\mathrm{msec})$ & $41.48 \pm 3.33^{\mathrm{a}, \mathrm{b}}$ & $61.35 \pm 3.24$ & $45.24 \pm 3.17^{\mathrm{a}, \mathrm{b}}$ & $29.63 \pm 3.37^{\mathrm{a}}$ \\
$\tau(60 \mathrm{mV})(\mathrm{msec})$ & $42.59 \pm 3.16^{\mathrm{a}, \mathrm{b}}$ & $65.67 \pm 3.03$ & $47.18 \pm 3.44^{\mathrm{a}, \mathrm{b}}$ & $31.49 \pm 3.24^{\mathrm{a}}$ \\
$\mathrm{V} 1 / 2(\mathrm{mV})$ & $-37.85 \pm 0.57$ & $-35.60 \pm 0.95$ & $-36.30 \pm 0.63$ & $-38.25 \pm 0.57$ \\
Slope factor $(\mathrm{mV})$ & $-4.80 \pm 0.50$ & $-4.24 \pm 0.19$ & $-4.62 \pm 0.39$ & $-4.92 \pm 0.56$ \\
Recovery & $36.74 \pm 1.48$ & $31.67 \pm 2.34$ & & $37.48 \pm 1.53$ \\
$\tau 1(\mathrm{msec})$ & $2,431.02 \pm 449.94$ & $2,549.92 \pm 433.76$ & $2,456.73 \pm 439.92$ & $2,378.83 \pm 458.71$ \\
$\tau 2(\mathrm{msec})$ & $93.26 \pm 4.69$ & $83.32 \pm 5.18$ & $91.03 \pm 4.27$ & $95.13 \pm 4.98$ \\
$\% \tau 1$ & $9.28 \pm 2.68$ & $16.32 \pm 5.04$ & $10.66 \pm 2.98$ & $9.07 \pm 2.71$ \\
$\% \tau 2$ & & & & \\
\hline
\end{tabular}

${ }^{\mathrm{a}} \mathrm{P}<0.05$, vs. SH group; ${ }^{\mathrm{b}} \mathrm{P}<0.05$, vs. los-WKY group. $\tau(0 \mathrm{mV}), \tau(20 \mathrm{mV}), \tau(40 \mathrm{mV})$ and $\tau(60 \mathrm{mV})$, inactivation time constant obtained at $\mathrm{V}=0,20,40$ and $60 \mathrm{mV}$, respectively; V1/2, voltage at which half-maximal steady-state inactivation was observed; slope factor, slope factor of the Boltzmann equation; $\tau 1, \tau 2$, time constants for recovery from inactivation; $\% \tau 1, \% \tau 2$, contribution of $\tau 1$ and $\tau 2$ to total recovery, values are presented in \% of total recovery. $I_{\text {to }}$, transient outward potassium current; WKY, Wistar-Kyoto; SH, spontaneously hypertensive; los-, losartan-treated.

Table V. Expression of Kv4.2, Kv4.3 and KChIP2 in vitro.

\begin{tabular}{|c|c|c|c|c|c|c|}
\hline \multirow[b]{2}{*}{ Groups } & \multicolumn{3}{|c|}{ mRNA, specific gene/GAPDH } & \multicolumn{3}{|c|}{ Protein, specific gene/GAPDH } \\
\hline & Kv4.2 & Kv4.3 & KChIP2 & Kv4.2 & Kv4.3 & KChIP2 \\
\hline WKY & $0.56 \pm 0.09^{\mathrm{a}, \mathrm{b}}$ & $0.64 \pm 0.08^{\mathrm{a}, \mathrm{b}}$ & $0.39 \pm 0.06^{\mathrm{a}, \mathrm{b}}$ & $0.73 \pm 0.10^{\mathrm{a}, \mathrm{b}}$ & $0.67 \pm 0.08^{\mathrm{a}, \mathrm{b}}$ & $0.58 \pm 0.11^{\mathrm{a}, \mathrm{b}}$ \\
\hline SH & $0.37 \pm 0.05$ & $0.36 \pm 0.06$ & $0.63 \pm 0.09$ & $0.43 \pm 0.80$ & $0.39 \pm 0.06$ & $0.82 \pm 0.13$ \\
\hline Los-SH & $0.54 \pm 0.06^{\mathrm{a}, \mathrm{b}}$ & $0.61 \pm 0.07^{\mathrm{a}, \mathrm{b}}$ & $0.41 \pm 0.07^{\mathrm{a}, \mathrm{b}}$ & $0.79 \pm 0.11^{\mathrm{a}, \mathrm{b}}$ & $0.65 \pm 0.07^{\mathrm{a}, \mathrm{b}}$ & $0.60 \pm 0.10^{\mathrm{a}, \mathrm{b}}$ \\
\hline Los-WKY & $0.64 \pm 0.07^{\mathrm{a}}$ & $0.74 \pm 0.07^{\mathrm{a}}$ & $0.31 \pm 0.08^{\mathrm{a}}$ & $0.92 \pm 0.11^{\mathrm{a}}$ & $0.81 \pm 0.09^{\mathrm{a}}$ & $0.34 \pm 0.08^{\mathrm{a}}$ \\
\hline
\end{tabular}

${ }^{\mathrm{a}} \mathrm{P}<0.01$, vs. SH group; ${ }^{\mathrm{P}}<0.05$, vs. los-WKY group. WKY, Wistar-Kyoto; SH, spontaneously hypertensive; los-, losartan-treated; Kv4.2 and 3 , potassium voltage-gated channel subfamily D members 2 and 3; KChIP2, voltage-gated potassium channel-interacting protein 2.

Table VI. Pearson correlation coefficients of the expression levels of Kv4.2, Kv4.3, KChIP2 with changes in blood pressure in losartan treatment group.

\begin{tabular}{|c|c|c|c|c|c|c|}
\hline \multirow[b]{2}{*}{ Parameters } & \multicolumn{2}{|c|}{ Kv4.2 } & \multicolumn{2}{|c|}{ Kv4.3 } & \multicolumn{2}{|c|}{ KChIP2 } \\
\hline & mRNA & Protein & mRNA & Protein & mRNA & Protein \\
\hline Correlation coefficients, $r$ & 0.07 & 0.08 & 0.06 & 0.06 & 0.05 & 0.04 \\
\hline
\end{tabular}

Kv4.2 and 3, potassium voltage-gated channel subfamily D members 2 and 3; KChIP2 voltage-gated potassium channel-interacting protein 2.

steadily increased with increasing $I_{\text {to }}$ density and expression of KChIP2 steadily decreased with increasing $I_{\text {to }}$ density.

Expression of Kv4.2, Kv4.3 and KChIP2 in vitro. In order to eliminate the effect of depressurization, isolated myocytes were directly treated with losartan in the in vitro experiments. The expression levels of Kv4.2 and Kv4.3 were significantly lower in SH compared with WKY, los-WKY and los-SH groups $(\mathrm{P}<0.01$; Table $\mathrm{V})$. The expression levels of Kv4.2 and Kv4.3 were significantly lower in WKY and los-SH compared with the los-WKY group $(\mathrm{P}<0.05)$. The expression levels of KChIP2 were significantly higher in $\mathrm{SH}$ 


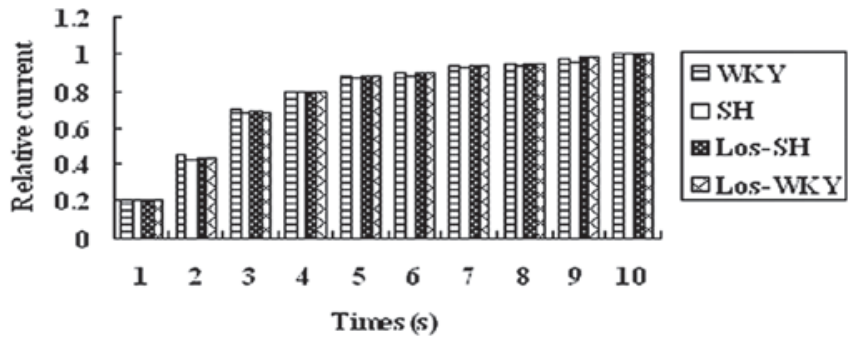

Figure 7. Recovery from inactivation of $I_{t o}$ was determined by two consecutive pulses of $60 \mathrm{mV}$ for $600 \mathrm{msec}$ each. During the interval between the two depolarizations, $\mathrm{V}$ was returned to $-90 \mathrm{mV}$. The interval between the voltage pulses ranged $10-7,500 \mathrm{msec}$ and increased exponentially with 1.5 being the exponent. Pulses were delivered at $0.1 \mathrm{~Hz} . I_{t o}$, transient outward potassium current; WKY, Wistar-Kyoto; SH, spontaneously hypertensive; los-, losartan-treated.

\section{mRNA expression of $\mathrm{Kv} 4.2, \mathrm{Kv} 4.3$ and $\mathrm{KChIP2}$}
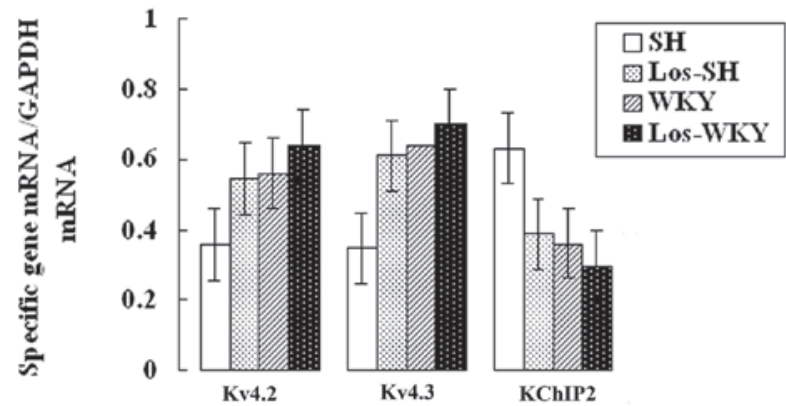

Figure 8. mRNA expression of Kv4.2, Kv4.3 and KChIP2 in vivo. The mRNA expression levels of Kv4.2 and Kv4.3 were significantly lower in myocytes from SH than in myocytes from WKY, los-WKY and los-SH groups $(\mathrm{P}<0.01)$. The mRNA expression levels of Kv4.2 and Kv4.3 were significantly lower in myocytes from WKY and los-SH than in myocytes from los-WKY group $(\mathrm{P}<0.05)$. The mRNA expression levels of KChIP2 were significantly higher in myocytes from SH than from WKY, los-WKY and los-SH groups $(\mathrm{P}<0.01)$. The mRNA expression levels of KChIP2 were significantly higher in myocytes from WKY and los-SH than in myocytes from the los-WKY group $(\mathrm{P}<0.05)$. WKY, Wistar-Kyoto; $\mathrm{SH}$, spontaneously hypertensive; los-, losartan-treated; Kv4.2 and 3, potassium voltage-gated channel subfamily D members 2 and 3; KChIP2, voltage-gated potassium channel-interacting protein 2.

compared with WKY, los-WKY and los-SH groups $(\mathrm{P}<0.01)$. The expression levels of KChIP2 were significantly higher in WKY and los-SH compared with los-WKY group $(\mathrm{P}<0.05)$. No significant difference in mRNA and protein expression levels of Kv4.2, Kv4.3 and KChIP2 was observed between WKY and los-SH groups $(\mathrm{P}>0.05)$.

Correlation analysis. In the losartan treatment group the Pearson correlation coefficients between expression levels of Kv4.2, Kv4.3 and KChIP2 and change in BP are shown in Table VI; those were not correlated with the change in BP.

\section{Discussion}

In the present study, the effect of chronic treatment with losartan on the electrophysiological alterations occurring in SH rats with cardiac hypertrophy was evaluated. The primary and novel finding of the present study is that blockade of AT
Protein expression of Kv4.2, Kv4.3 and KClIP2

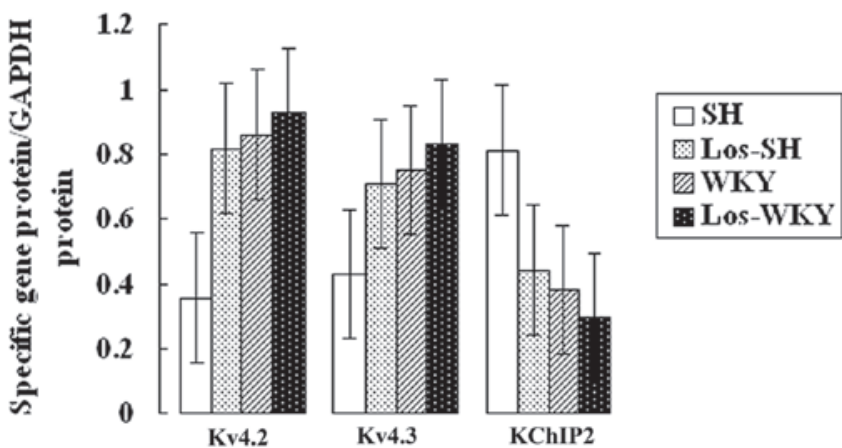

Figure 9. Protein expression of Kv4.2, Kv4.3 and KChIP2 in vivo. Protein expression levels of Kv4.2 and Kv4.3 were significantly lower in myocytes from $\mathrm{SH}$ than in myocytes from WKY, los-WKY and los-SH groups $(\mathrm{P}<0.01)$. Protein expression levels of Kv4.2 and Kv4.3 were significantly lower in myocytes from WKY and los-SH than in myocytes from the los-WKY group $(\mathrm{P}<0.05)$. Protein expression levels of KChIP2 were significantly higher in myocytes from the $\mathrm{SH}$ than from WKY, los-WKY and los-SH groups $(\mathrm{P}<0.01)$. Protein expression levels of KChIP2 were significantly higher in myocytes from WKY and los-SH than in myocytes from los-WKY group $(\mathrm{P}<0.05)$. WKY, Wistar-Kyoto; SH, spontaneously hypertensive; los-, losartan-treated; Kv4.2 and 3, potassium voltage-gated channel subfamily D members 2 and 3; KChIP2, voltage-gated potassium channel-interacting protein 2.

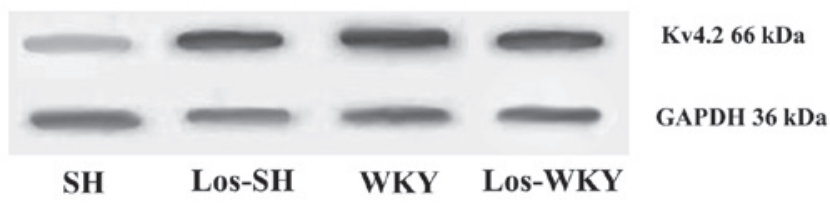

Figure 10. Representative western blot of Kv4.2 in rat heart left ventricles. WKY, Wistar-Kyoto; SH, spontaneously hypertensive; los-, losartan-treated; Kv4.2, potassium voltage-gated channel subfamily D member 2.

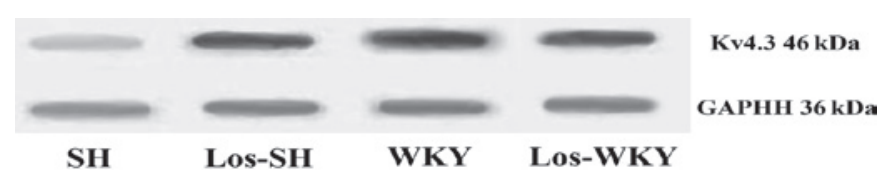

Figure 11. Representative western blot of Kv4.3 in rat heart left ventricles. WKY, Wistar-Kyoto; SH, spontaneously hypertensive; los-, losartan-treated; Kv4.3, potassium voltage-gated channel subfamily D member 3.

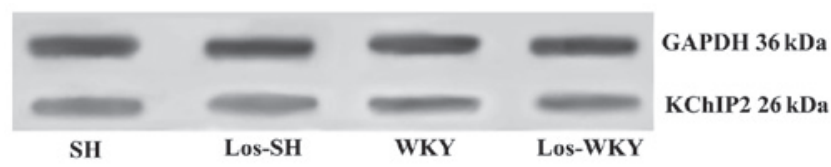

Figure 12. Representative western blot of KChIP2 in rat heart left ventricles. WKY, Wistar-Kyoto; SH, spontaneously hypertensive; los-, losartan-treated; KChIP2, voltage-gated potassium channel-interacting protein 2.

not only affects the electrophysiological alterations (APD, $I_{\text {to }}$ density), but also affects the expression of $\mathrm{Kv} 4.2, \mathrm{Kv} 4.3$ and KChIP2, which contribute to $I_{\text {to }}$, in myocytes isolated from the rat heart; however, this occurred independent of changes in BP. Losartan may decrease the inactivation time by increasing the expression of KChIP2. 
The primary ionic alteration responsible for action potential prolongation caused by chronic hypertension is a specific decrease in $I_{\text {to }}$, while the other currents influencing repolarization $\left(I_{\mathrm{Ca}}\right.$ and $I_{\mathrm{k}}$ ) remain unmodified (5). AP prolongation at the early stages of cardiac hypertrophy may be linked to the upregulation of $I_{\mathrm{Ca}}$ and the downregulation of $I_{\mathrm{to}}$. Once cellular hypertrophy is established, only reduced $I_{\text {to }}$ persists, whereas $I_{\mathrm{Ca}}$ values regain control levels. After 3 weeks, the decrease in repolarization of $I_{\text {to }}$ results in prolongation of AP (11). In the human myocardium, the duration of the action potential is largely determined by several outward $\mathrm{K}^{+}$currents $(9,12-13)$, including i) the 4-aminopyridine-sensitive component of $I_{\text {to }}$ carried by Kv4.3 $\alpha$-subunits, possibly coassembled with the auxiliary $\beta$-subunits of KChIP2; ii) the rapidly activating, slowly inactivating delayed rectifier current generated by hKv1.5 channels; and iii) the fast $\left(I_{\mathrm{Kr}}\right)$ and slow $\left(I_{\mathrm{Ks}}\right)$ components of the delayed rectifier current. The native $I_{\mathrm{Kr}}$ current is carried by channels formed by the coassembly of human ether-à-go-go-related gene $\alpha$-subunits and MinK-related peptide $1 \beta$-subunits, whereas coassembly of KvLQT1 (a voltage-gated potassium channel expressed in cardiac cells that is critical for myocardial repolarization) $\alpha$-subunits with MinK (a 129-amino-acid protein containing one transmembranespanning domain that modulates KvLQT1, slowing activation, increasing current amplitude and removing inactivation) $\beta$-subunits produces the $I_{\mathrm{Ks}}$ current. It has been previously established that the repolarizing current $I_{\text {to }}$ is the main current controlling the repolarization phase in the rat (5). A large fraction of the increase in APD has been attributed to a decrease in the $\mathrm{Ca}^{2+}$-independent $I_{\mathrm{to}}$. Elimination of $I_{\mathrm{to}}$ results in a marked increase in mouse ventricular APD and cardiac remodeling. $I_{\text {to }}$ is important in repolarization in the mouse ventricle (9). The present study demonstrates APD prolongation, $I_{\text {to }}$ reduction, downregulation of Kv4.2 and Kv4.3 (mRNAs and protein) and upregulation of KChIP2 (mRNAs and protein) in SH rats with cardiac hypertrophy. Thus, the present study suggests that systemic hypertension may decrease $I_{\text {to }}$ density by reducing the expression of Kv4.2 and Kv4.3 transcripts and by increasing the expression of KChIP2 transcripts. The results are consistent with those of a previous study (14).

In $\mathrm{SH}$ rats, LV hypertrophy resembles the changes observed in patients with hypertension and antihypertensive drugs may protect the heart from LV hypertrophy. ARBs have increasingly become part of the first line of treatment against hypertensive diseases and losartan was shown to improve cardiovascular morbidity and mortality in patients with isolated systolic hypertension and LV hypertrophy (2). It has been observed that cardiac hypertrophy secondary to systemic hypertension is associated with increases in the incidence of sudden mortality and cardiac morbidity (1). Irrespective of etiology, APD prolongation is a common electrophysiological feature of the hypertrophied cardiomyocyte, which is involved in a higher propensity to arrhythmias. In middle-aged SH rats the incidence of VAs is higher compared with age-matched normotensive rats (3). Abnormalities in repolarization may predispose to dispersion of repolarization, leading to no excitable gap reentry. Additionally, AP prolongation favors the development of early afterdepolarizations, which may induce triggered arrhythmias (2). A number of $\mathrm{AT}_{1}$ antagonists, including losartan and candesartan, at clinically relevant concentrations, directly modi- fied the human cardiac repolarizing $\mathrm{K}^{+}$currents (1). Previously, it has been demonstrated that the $\mathrm{AT}_{1}$ antagonist losartan directly modified human cardiac repolarizing $\mathrm{K}^{+}$currents (2). Blockade of $\mathrm{AT}_{1}$ not only affects the development of cardiac and cellular hypertrophy, but also affects electrophysiological alterations. Chronic blockade of $\mathrm{AT}_{1}$ receptors affects cardiac ionic currents. It is already known that chronic treatment with an AT antagonist is capable of preventing action potential prolongation (1). Losartan prevents stretch-induced electrical remodeling in neonatal cultured atria rat myocytes (15-16). The present study demonstrates that chronic blockade of $\mathrm{AT}_{1}$ receptors with losartan shows a trend toward improvement in hypertrophy, but it was not significant. This may be a consequence of depressurization. The present study demonstrates that chronic blockade of $\mathrm{AT}_{1}$ receptors with losartan reverses $\mathrm{SH}$ rat electrical remodeling, resulting in shortening of APD, which is associated with increasing $I_{\text {to }}$ density by increased mRNA and protein expression of Kv4.2, Kv4.3 and by decreased mRNA and protein expression of KChIP2. The results of the present study are consistent with those of a previous study (6). That losartan reverses $\mathrm{SH}$ rat electrical remodeling may be a consequence of depressurization. It has previously been demonstrated that the $\mathrm{AT}_{1}$ receptor antagonist reduces the heart rate and QT dispersion in hypertensive patients, and the two effects were independent of changes in BP (2). The present study demonstrates that the Pearson statistical test showed no correlation between mRNA and protein expression levels of Kv4.2, Kv4.3 and KChIP2 and changes in BP in the losartan treatment group. In addition, direct treatment of isolated myocytes with losartan in the in vitro experiments demonstrates that losartan regulates mRNA and protein expression of Kv4.2, Kv4.3 and KChIP2. This indicates that losartan may directly modify the cardiac repolarizing $\mathrm{K}^{+}$ currents by reducing the expression of Kv4.2 and Kv4.3 transcripts and by increasing the expression of KChIP2 transcripts.

Inactivation of $I_{\mathrm{to}}$, which is negatively modulated by KChIP2, was slowed down in SH rats, while recovery from inactivation remained unchanged. Expression of increasing amounts of KChIP2, together with a fixed amount of Kv4.2 revealed a hyperbolic correlation between the recovery from inactivation and the inactivation time constant, demonstrating that KChIP2 preferentially affects inactivation, if its expression level is high. The present study demonstrates that the inactivation time constant was larger in myocytes isolated from SH compared with that of the WKY group. The results are consistent with published work (5). Furthermore, the inactivation time constant was observed to be smaller in myocytes isolated from los-SH compared with the $\mathrm{SH}$ group and that the decrease in the inactivation time constant is associated with increasing mRNA and protein expression of KChIP2. This means that losartan may decrease the inactivation time by increasing the expression of KChIP2 transcripts.

In conclusion, chronic blockade of $\mathrm{AT}_{1}$ receptors with losartan reverses $\mathrm{SH}$ rat electrical remodeling, resulting in shortening of APD, which is associated with increasing $I_{\text {to }}$ density caused by an increased mRNA and protein expression of Kv4.2, Kv4.3 and a decreased mRNA and protein expression of KChIP2. Losartan may decrease the inactivation time by increasing the expression of KChIP2 transcripts. Losartan regulated the expression of Kv4.2, Kv4.3 and KChIP2 transcripts, which was independent of changes in BP. 
The present study was limited by the fact that it focused only on $I_{\mathrm{to}}$. Other currents, including $I_{\mathrm{K} 1}, I_{\mathrm{Kr}}, I_{\mathrm{Ks}}$ and $I_{\mathrm{Ca}, \mathrm{L}}$, which have also been reported to contribute to repolarization in rat ventricles, were not assessed (5). Additional studies are required to determine the effect of chronic treatment with losartan on $I_{\mathrm{K} 1}, I_{\mathrm{Kr}}, I_{\mathrm{Ks}}$ and $I_{\mathrm{Ca}, \mathrm{L}}$ in the rat heart and in the human heart. Another limitation is that the effects of losartan on $I_{\text {to }}$ and Kv4.2, Kv4.3 and KChIP2 expression were not studied. For example, a previous study concluded that calcineurin $(\mathrm{Cn})$, a $\mathrm{Ca}^{2+} /$ calmodulin-activated serine/threonine phosphatase causes reductions in $I_{\text {to }}(2)$. Additional studies are required to investigate the correlation between $\mathrm{Cn}$ and losartan in the regulation of $I_{\text {to }}$ in rat ventricles.

\section{Acknowledgements}

The authors would like to thank Dr Xu Lin for his assistance with the qPCR and patch-clamp assays.

\section{References}

1. Bhuriya R, Singh M, Sethi A, Molnar J, Bahekar A, Singh PP, Khosla S and Arora R: Prevention of recurrent atrial fibrillation with angiotensin-converting enzyme inhibitors or angiotensin receptor blockers: a systematic review and meta-analysis of randomized trials. J Cardiovasc Pharmacol Ther 16: 178-184, 2011.

2. Novo S, Lunetta M, Evola S and Novo G: Role of ARBs in the blood hypertension therapy and prevention of cardiovascular events. Curr Drug Targets 10: 20-25, 2009.

3. Makkar KM, Sanoski CA and Spinler SA: Role of angiotensin-converting enzyme inhibitors, angiotensin II receptor blockers, and aldosterone antagonists in the prevention of atrial and ventricular arrhythmias. Pharmacotherapy 29: 31-48, 2009.

4. Johnston K and Stephens S: Effect of angiotensin-converting enzyme inhibitors and angiotensin receptor blockers on risk of atrial fibrillation before coronary artery bypass grafting. Ann Pharmacother 46: 1239-1244, 2012.
5. Chae JE, Kim HS, Ahn DS and Park WK: Ionic mechanisms of desflurane on prolongation of action potential duration in rat ventricular myocytes. Yonsei Med J 53: 204-212, 2012.

6. Thomsen MB, Foster E, Nguyen KH and Sosunov EA: Transcriptional and electrophysiological consequences of KChIP2-mediated regul ation of CaV1.2. Channels (Austin) 3: 308-310, 2009.

7. Diez ER, Renna NF, Prado NJ, Lembo C, Ponce Zumino AZ, Vazquez-Prieto M and Miatello RM: Melatonin, given at the time of reperfusion, prevents ventricular arrhythmias in isolated hearts from fructose-fed rats and spontaneously hypertensive rats. J Pineal Res 55: 166-173, 2013.

8. Cha JH, Lee HR, Kim KC, Cho MS and Hong YM: Changes of gene expressions in spontaneously hypertensive rat model after losartan treatment. Korean Circ J 42: 761-768, 2012.

9. El Gebeily G and Fiset C: 4-Hydroxytamoxifen inhibits $\mathrm{K}(+)$ currents in mouse ventricular myocytes. Eur J Pharmacol 629: 96-103, 2010.

10. Stenman E and Edvinsson L: Cerebral ischemia enhances vascular angiotensin AT1 receptor-mediated contraction in rats. Stroke 35: 970-974, 2004.

11. Li Q, Ma HJ, Song SL, Shi M, Ma HJ, Li DP and Zhang Y: Effects of anandamide on potassium channels in rat ventricular myocytes: a suppression of I(to) and augmentation of K(ATP) channels. Am J Physiol Cell Physiol 302: C924-C930, 2012.

12. Cordeiro JM, Calloe K, Moise NS, Kornreich B, Giannandrea D, Di Diego JM, Olesen SP and Antzelevitch C: Physiological consequences of transient outward $\mathrm{K}^{+}$current activation during heart failure in the canine left ventricle. J Mol Cell Cardiol 52: 1291-1298, 2012.

13. Giudicessi JR and Ackerman MJ: Potassium-channel mutations and cardiac arrhythmias - diagnosis and therapy. Nat Rev Cardiol 9: 319-332, 2012.

14. Wagner M, Rudakova E, Schütz V, Frank M, Ehmke H and Volk T: Larger transient outward $\mathrm{K}(+)$ current and shorter action potential duration in Galpha(11) mutant mice. Pflugers Arch 459: 607-618, 2010

15. Goette A, Schön N, Kirchhof P, Breithardt G, Fetsch T, Häusler KG, Klein HU, Steinbeck G, Wegscheider K and Meinertz T: Angiotensin II-antagonist in paroxysmal atrial fibrillation (ANTIPAF) trial. Circ Arrhythm Electrophysiol 5: 43-51, 2012.

16. Jiao KL, Li YG, Zhang PP, Chen RH and Yu Y: Effects of valsartan on ventricular arrhythmia induced by programmed electrical stimulation in rats with myocardial infarction. J Cell Mol Med 16: 1342-1351, 2012. 